\title{
Vaginal microflora associated with bacterial vaginosis in nonpregnant women: reliability of sialidase detection
}

\author{
Jorgelina Smayevsky, Liliana Fernández Canigia, Alejandra Lanza \\ and Hebe Bianchini \\ Laboratorio de Microbiología, Centro de Educación Médica e Investigaciones Clínicas \\ Dr. Norberto Quirno CEMIC, Buenos Aires, Argentina
}

\begin{abstract}
Objective: To determine the prevalence of Gardnerella vaginalis, anaerobic bacteria and Mycoplasma hominis in vaginal specimens of women with and without bacterial vaginosis (BV) as well as to determine the sensitivity and specificity of the direct sialidase assay of vaginal fluid as a rapid test for diagnosing this syndrome.

Methods: Vaginal cultures were obtained from 109 nonpregnant women (mean age $33 \pm 7.1$ years), 47 of them with clinical signs of $B V(B V+)$ and 62 of them without $B V(B V-)$. In addition, we determined the vaginal sialidase activity in both groups, which may serve as a feature of this syndrome.

Results: Anaerobic bacteria were isolated in $91 \%$ and $18 \%$ of the $B V+$ and $B V-$ groups, respectively $(p<0.001)$. Peptostreptococcus spp., Prevotella bivia and Porphyromonas spp. were strongly associated with BV. P. bivia and Prevotella spp. represented $44 \%$ of all the anaerobes isolated in the BV+ group. All the isolated $P$. bivia strains presented sialidase activity. G. vaginalis and $M$. hominis were isolated in $76 \%$ and $42 \%$ of the $B V+$ and $1 \%$ and $0 \%$ of the BV-women, respectively $(p<0.00 \mathrm{I})$. Mobiluncus morphotypes were observed in $34 \%$ of the BV + and $0 \%$ of BV- women. Sensitivity, specificity, positive predictive value and negative predictive value of sialidase activity were $81 \%, 94 \%, 90 \%$ and $86 \%$, respectively.
\end{abstract}

Conclusions: Our data demonstrate a strong association between G. vaginalis, M. hominis, and P. bivia and BV. Sialidase activity and Gram stain of vaginal fluid represent accurate methods for diagnosing BV.

Key words: VAGINOSIS; ANAERoBes; DiAgNOSIS

Bacterial vaginosis, previously known as nonspecific vaginitis, Haemophilus vaginalis vaginitis, Corynebacterium vaginale vaginitis, Gardnerella vaginalis vaginitis and anaerobic vaginosis, is an abnormal condition of the vaginal ecosystem caused by overgrowth of both aerobic and anaerobic vaginal bacteria flora ${ }^{1-4}$. It is the most common vaginal disorder in women of reproductive age and is responsible for approximately one-third of all cases of vulvovaginitis. It is now regarded as a risk factor for complications of pregnancy, including chorioamnionitis and prematurity ${ }^{5-9}$.
Bacterial vaginosis represents a synergistic polymicrobial infection, characterized by an overgrowth of bacterial species usually found in the vagina. The lactobacilli-dominated flora is replaced by a mixed flora, consisting of Gardnerella vaginalis; anaerobes such as Bacteroides spp., Prevotella spp. and Mobiluncus spp.; and Mycoplasma hominis ${ }^{10}$.

Several bacterial enzymes, including sialidases, have been implicated as virulence factors in pregnancy complications such as prematurity and chorioamnionitis. Sialidases, formerly known

Correspondence to: Jorgelina Smayevsky, PhD, Camargo 581, Piso 4, Buenos Aires 1414, Argentina. E-mail: JSmayevsky@cemic.edu.ar 
as neurominidases, are enzymes that cleave $\alpha$-ketosidic linkages between the glycosyl residues of glycoproteins, glycolipids and sialic acids ${ }^{11}$. The purpose of this study was to determine the prevalence of Gardnerella vaginalis, anaerobic bacteria and Mycoplasma hominis in vaginal specimens from women with and without bacterial vaginosis, as well as to determine the sensitivity and specificity of the direct sialidase assay on vaginal fluid as a rapid test for diagnosing this syndrome.

\section{MATERIALS AND METHODS}

In total 109 women (mean age $33 \pm 7.1$ years) were studied. Forty-seven women with BV were included in the BV group. Sixty-two women from the same hospital, free of BV, were included as controls. All women were nonpregnant, and none was menstruating at the time of examination. Women were excluded from the study when they had used antibiotics 3 days before the study.

$\mathrm{BV}$ was defined by the presence of vaginal $\mathrm{pH}$ $>4.5$, fishy odor-positive in presence of $10 \%$ $\mathrm{KOH}$ (positive whiff test), and presence of clue cells. Controls (women without BV) were defined by the absence of all these three clinical criteria. Homogeneous vaginal discharge was not considered. Specimens were taken from the posterior vaginal fornix using a sterile, nonlubricated speculum. Odor was tested by immersing a swab containing the vaginal fluid in $10 \% \mathrm{KOH}$ and smelling the odor. The $\mathrm{pH}$ of vaginal secretions was measured with $\mathrm{pH}$ paper (Spezialindikator $\mathrm{pH}$ 4.0-7.0; Merck). A second vaginal swab was collected in saline solution and examined microscopically for bacterial morphologic types, clue cells, white cells, trichomonads and yeasts by wet mount $(\times 400)$.

Gram stain was performed using a third swab and evaluated for bacterial morphologic types using Nugent's score $(\times 1000)^{12}$. Women were categorized as BV-positive (scores 7-10) and BV-negative (score < 7 ) using the Gram stain scoring system for vaginal smears. Having more than 10 polymorphonuclear cells per field $(\times 1000)$ was considered as a significant inflammatory reaction.

Three other vaginal swabs were placed into Cary Blair transport medium, into anaerobic transport medium, and into mycoplasma transport medium. Another vaginal swab was collected to perform a sialidase activity assay. Endocervical swab specimens were taken for screening for Neisseria gonorrhoeae and Chlamydia trachomatis.

Vaginal swabs were placed onto chocolate agar, human blood agar, modified Thayer-Martin medium and Feimberg medium, as described elsewhere $^{13}$. G. vaginalis cultures recovered from the third and fourth streak zones on an agar plate were considered significant.

Brucella blood agar + vitamin $\mathrm{K}(1 \mu \mathrm{g} / \mathrm{ml})+$ hemin $(5 \mu \mathrm{g} / \mathrm{ml})$ and brucella blood agar + $\mathrm{K} \quad$ vitamin $(1 \mu \mathrm{g} / \mathrm{ml})+$ hemin $(5 \mu \mathrm{g} / \mathrm{ml})+$ amikacin $(50 \mu \mathrm{g} / \mathrm{ml})$ were incubated for 7 days at $35^{\circ} \mathrm{C}$ in an anaerobic chamber ${ }^{14}$. All other plates were incubated at $37^{\circ} \mathrm{C}$ in $5 \% \mathrm{CO}_{2}$ for $96 \mathrm{~h}$. Feimberg medium was incubated in air for $96 \mathrm{~h}$. Mobiluncus culture was not performed.

Ureaplasma urealyticum and Mycoplasma hominis were cultivated in urea broth, arginine broth and A7 Sheppard agar and incubated for 5 days at $35^{\circ} \mathrm{C}$ in $5 \% \mathrm{CO}_{2}$ atmosphere. U. urealyticum cultures were considered as significant when the colony count was higher than $10^{4} \mathrm{ccu} / \mathrm{ml}^{15}$.

Aerobic and facultative anaerobic isolates were identified by conventional methods ${ }^{13,16}$. Anaerobic bacteria growing in the third and fourth streaks were identified by performing biochemical tests ${ }^{14,17}$. Sialidase activity of anaerobic bacteria was measured by a filter-paper spot test ${ }^{18}$. Selective medium for lactobacilli was not used.

Specimens in 2SP medium were stored frozen at $-70^{\circ} \mathrm{C}$ for up to 5 days. Aliquots of $250 \mu 1$ were inoculated onto $\mathrm{McCoy}$ cells monolayers growing on glass coverslips in shell vials by standard methods $^{19}$. The tissue cultures were incubated at $35^{\circ} \mathrm{C}$ in a $5 \% \mathrm{CO}_{2}$ atmosphere. After $72 \mathrm{~h}$ the cultures were stained with Jones's iodine stain and examined microscopically for chlamydial inclusions.

Sialidase activity was qualitatively determined by a filter-paper spot test using a stock solution of 2'-(4-methylumbelliferyl) $\alpha-\mathrm{D}-\mathrm{N}$-acetyl-neuraminic acid in buffer acetate. Prior to use, it was diluted and filter paper strips were saturated with this solution. Paper strips were then inoculated with a spot of vaginal fluid and incubated for $15 \mathrm{~min}$ at $37^{\circ} \mathrm{C}$. The test was interpreted by 
Table I Prevalance of microorganisms in the vaginal fluid of 109 women with and without bacterial vaginosis (BV)

\begin{tabular}{|c|c|c|c|c|c|}
\hline \multirow[b]{2}{*}{ Microorganisms isolated* } & \multicolumn{2}{|c|}{$\begin{array}{c}B V+ \\
(n=47)\end{array}$} & \multicolumn{2}{|c|}{$\begin{array}{c}B V- \\
(n=62)\end{array}$} & \multirow[b]{2}{*}{$\mathrm{p}$ value** } \\
\hline & Number & Percentage & Number & Percentage & \\
\hline \multicolumn{6}{|l|}{ Anaerobic Gram-negative rods } \\
\hline Prevotella bivia & 22 & 47 & 1 & I & $<0.001$ \\
\hline P. intermedia & 3 & 6 & I & I & NS \\
\hline P. disiens & I & 2 & 0 & 0 & NS \\
\hline Prevotella spp. & 5 & 10 & 0 & 0 & NS \\
\hline Porphyromonas asacharolytica & 17 & 36 & I & 1 & $<0.05$ \\
\hline Porphyromonas spp. & 3 & 6 & I & I & NS \\
\hline Bacteroides spp. & 3 & 6 & 0 & 0 & NS \\
\hline \multicolumn{6}{|l|}{ Anaerobic Gram-positive rods } \\
\hline Mobiluncus morphotypes & 16 & 34 & 0 & 0 & $<0.01$ \\
\hline \multicolumn{6}{|l|}{ Anaerobic Gram-positive cocci } \\
\hline Peptostreptococcus spp. & 23 & 49 & 8 & 13 & $<0.001$ \\
\hline \multicolumn{6}{|l|}{ Facultative anaerobic bacteria } \\
\hline Gardneralla vaginalis & 36 & 76 & I & I & $<0.001$ \\
\hline Streptococcus agalactiae & 2 & 4 & 5 & 8 & NS \\
\hline \multicolumn{6}{|l|}{ Mycoplasmas } \\
\hline Mycoplasma hominis & 20 & 42 & 0 & 0 & $<0.001$ \\
\hline Ureaplasma urealyticum & 10 & 21 & 9 & 14 & $<0.05$ \\
\hline \multicolumn{6}{|l|}{ Yeasts } \\
\hline Candida albicans & 2 & 4 & 7 & II & NS \\
\hline
\end{tabular}

*T. vaginalis, $N$. gonorrhoeae and C. trachomatis have not been isolated; **the $\chi^{2}$ tests and the Fisher's exact test were used

examining the strips under a long-wavelength (365 nm) lamp. A fluorescent blue spot was indicative of sialidase activity ${ }^{11}$.

The $\chi^{2}$ tests, Fisher's exact test and MannWhitney test were used for comparative analysis of the data obtained, and significance was assigned at $p<0.05$.

\section{RESULTS}

The prevalence of microorganisms isolated in the vaginal fluid in women with and without $\mathrm{BV}$ is shown in Table 1. Neither Neisseria gonorrhoeae nor Chlamydia trachomatis was isolated. Anaerobic bacteria were isolated in $91 \%$ and $18 \%$ of the women with and without $\mathrm{BV}$, respectively $(p<0.001)$.

The mean number of isolates per specimen from women with BV was $\sim 4-7$ times more than that from those without BV (Table 2). Peptostreptococcus spp., P. bivia, and Porphyromonas spp. were strongly
Table 2 Number of isolates in vaginal samples of 109 women with and without bacterial vaginosis (BV)

\begin{tabular}{lcccc}
\hline & $\begin{array}{c}\text { Women } \\
\text { with BV } \\
(\mathrm{n}=47)\end{array}$ & $\begin{array}{c}\text { Women } \\
\text { without BV } \\
(\mathrm{n}=62)\end{array}$ & p value* \\
Isolates & 163 & 34 & \\
\hline $\begin{array}{l}\text { Total number } \\
\begin{array}{l}\text { Mean } \pm \text { SD per } \\
\text { specimen }\end{array}\end{array}$ & $3.47 \pm \mathrm{I} .20$ & $0.55 \pm 0.7 \mathrm{I}$ & $<0.001$ \\
\hline
\end{tabular}

Values are reported as mean \pm standard deviation (SD); *the Mann-Whitney test was used

associated with BV $(p<0.001)$. P. bivia and Prevotella spp. represented $44 \%$ of all of the anaerobes isolated in the $\mathrm{BV}+$ group.

G. vaginalis and $M$. hominis were isolated in $76 \%$ and $42 \%$ of the women with BV and in $1.0 \%$ and $0 \%$ of the women without $\mathrm{BV}$, respectively $(p<0.001)$. These data showed a strong association between each microorganism and BV. 
Mobiluncus morphotypes were observed only in $34 \%$ of the BV+ group.

All of 33 P. bivia strains as well as one of the five isolates of Prevotella spp. and one of one isolate of $P$. disiens presented sialidase activity. Vaginal sialidase activity was detected in $81 \%$ of the women with BV but in only $6 \%$ in the control group $(p<0.001)$. Overall, positive predictive value $(\mathrm{PPV})$ and negative predictive value (NPV) of the vaginal sialidase test for BV diagnosis were $90 \%$ and $86 \%$, respectively. Sialidase-positive bacteria were recovered from $51 \%$ of the women with BV and from only one patient (1\%) among those without BV.

By the Gram stain scoring system for vaginal smear, women with BV were categorized as follows: $2 \%$ had intermediate vaginal flora (scores $4-6$ ) and $98 \%$ had BV vaginal flora (score $\geq 7$ ). No women with BV had normal vaginal flora (scores $0-3$ ). Ninety-two per cent of the women without BV had normal vaginal flora (scores $0-3$ ), $6 \%$ had intermediate vaginal flora and $2 \%$ had BV vaginal flora. The PPV and NPV of the Gram stain scoring system were $98 \%$ and $98 \%$, respectively.

We did not find any statistical difference between the inflammatory reaction observed in the vaginal Gram stains of the two groups. Four per cent of the patients of the $\mathrm{BV}+$ group and $11 \%$ of the patients of the BV- group presented significant inflammatory reaction (PPV 22\%, NPV 55\%).

\section{DISCUSSION}

To our knowledge this is the first microbiology study of the vaginal microflora of nonpregnant women with and without BV in our country, with special emphasis on anaerobic bacteria. We defined $\mathrm{BV}$ by the presence of vaginal $\mathrm{pH}>4.5$, fishy odor positivity in the presence of $10 \% \mathrm{KOH}$ (positive whiff test), and presence of clue cells. We decided not to consider homogeneous vaginal discharge because of its low $\mathrm{PPV}^{20}$. Thomason et al. ${ }^{20}$ speculated that this poor predictive value may be attributable to interexaminer variability of this criterion. In the same study, the authors concluded that homogeneous discharge was of little diagnostic value.
Nevertheless, we did not use quantitative methodologies, similar to those used by Hillier et al. ${ }^{21}$; we isolated Prevotella species, Peptostreptococcus spp., and $P$. asacharolytica in most women with BV. These results agree with those published by Puapermpoonsiri and colleagues ${ }^{22}$. who isolated Prevotella species (mainly P. bivia), Porphyromonas species and Peptostreptococcus species significantly associated with BV in pregnant Japanese and Thai women. These authors also found that the mean number of organisms recovered in the $\mathrm{BV}+$ group is twice as high as that in the control group ${ }^{22}$.

We found a very good sensitivity and specificity of the sialidase activity in the vaginal fluid. Briselden et al. ${ }^{11}$ described sialidase activity in $84 \%$ of women with BV and in none of 19 women with normal vaginal flora. Furthermore, vaginal sialidase was eradicated in $95 \%$ of the women after successful treatment but in none of the women with persistent or recurrent $\mathrm{BV}^{11}$. Smayevsky et al. ${ }^{23}$ found also a very good sensitivity and a specificity of a vaginal sialidase assay in 316 nonpregnant women (92\% and 94\%, respectively).

Prevotella species were the only anaerobic bacteria displaying sialidase activity. These data suggest that the presence of sialidase activity in the vaginal fluid of women with $\mathrm{BV}$ is mainly associated with the presence of sialidase-positive P. bivia. Briselden et al. ${ }^{11}$ found that all of the 83 $P$. bivia isolates studied were positive for sialidase activity, compared to $12(38 \%)$ of $32 \mathrm{P}$. disiens isolates.

The production of sialidase by the anaerobes associated with prematurity suggests that the enzyme may be involved. Studies have demonstrated that tissue exposure to sialidases eliminates the subterminal sugars, resulting in an increased adherence capability and invasion and destruction of mucosal tissue $\mathrm{e}^{3,24}$. The presence of $P$. bivia in vaginal fluid has been recently correlated with an important increase in premature birth ${ }^{4,7,8,25}$.

We detected Mobiluncus morphotypes in 34\% of the women with BV and in none of the 62 women without BV. These results agree with those of Spiegel et al. ${ }^{26}$ and Puapermpoonsiri et al. ${ }^{22}$, but these authors did perform cultures for detecting Mobiluncus species. 
We isolated $M$. hominis in $42 \%$ of the women with BV. Taylor-Robinson ${ }^{27}$ isolated M. hominis in $60 \%$ of the women with BV and in $10 \%$ of the women without BV, and Smayevsky et al. ${ }^{28}$ described, for women with BV, a strong association between M. hominis and G. vaginalis (82\%). These data emphasize the close correlation between $M$. hominis and BV.

It has already been noted that $G$. vaginalis can be recovered from vaginal fluid of normal women ${ }^{1,2}$. Several authors have described $G$. vaginalis isolation rates ranging from $36 \%$ to $55 \%$ in women without $\mathrm{BV}^{2,3,6}$. In contrast, we found $G$. vaginalis in only $1 \%$ of the women without BV. This difference may be explained on the basis of inclusion criteria and methodology differences. First, we defined our negative control group (women without BV) as patients in whom none of the three clinical signs - $\mathrm{pH}$, whiff test, and clue cells - was present, whereas women who did not meet three of the four Amsel criteria were included in the non-BV group by others. On the other hand, we considered significant G. vaginalis growth, recovered from third and fourth streaks.

Our study is in agreement with previous data showing that the presence of a significant inflammatory reaction is neither sensitive nor specific for diagnosing $\mathrm{BV}^{20}$, because $\mathrm{BV}$ is considered to be a noninflammatory disease ${ }^{2}$. We conclude that anaerobic bacteria, especially $P$. bivia, G. vaginalis and $M$. hominis, are the organisms most involved in BV. The sialidase activity in vaginal fluid and the Gram stain scoring system represent accurate, rapid and inexpensive methods for detection of bacterial vaginosis.

\section{REFERENCES}

1. Isson C, Taylor-Robinson D. Bacterial vaginosis. Int J STD AIDS 1997;8:2-3

2. Eschenbach D, Hillier SL, Crichlow C, et al. Diagnosis and clinical manifestations of bacterial vaginosis. Am J Obstet Gynecol 1988;158:819-28

3. Amsel R, Totten PA, Spiegel CA, et al. Nonspecific vaginitis: diagnostic criteria and microbial and epidemiologic associations. Am J Med 1983; 74:14-22

4. Holst EB, Wathne B, Hovelius B, et al. Bacterial vaginosis: microbiological and clinical findings. Eur J Clin Microbiol 1967;6:536-41

5. Hillier SL, Maritus J, Krohn M, et al. A case control study of chorioamnionic infection and histologic chorioamnionitis in prematury. N Engl J Med 1988; 319:972-8

6. Hillier SL. Diagnostic microbiology of bacterial vaginosis. Am J Obstet Gynecol 1993;169:455-9

7. Gravett M, Hummel D, Eschenbach D, Holmes KK. Preterm labor associated with subclinical amniotic fluid infection and with bacterial vaginosis. Obstet Gynecol 1986;67:229-37

8. Clark P, Kurtzer P, Duff P. Role of bacterial vaginosis in peripartum infections. Infect Dis Obstet Gynecol 1994;2:179-83

9. Holst EB, Goffeng A, Andersch B. Bacterial vaginosis and vaginal microorganisms in idiopathic premature labor and association with pregnancy outcome. J Clin Microbiol 1994;32:176-86
10. Spiegel CA. Bacterial vaginosis: changes in laboratory practice. Clin Microbiol Newslett 1999; 21:33-7

11. Briselden A, Moncla B, Stevens C, Hillier SL. Sialidases in bacterial vaginosis and bacterial vaginosis-associated microflora. J Clin Microbiol 1992;30:663-6

12. Nugent R, Krohn M, Hillier SL. Reliability of diagnosing bacterial vaginosis is improved by a standardized method of Gram stain interpretation. J Clin Microbiol 1991;29:297-301

13. Baron EJ, Cassel G, Duffy L, et al. Cumitech 17 A: Laboratory Diagnosis of Female Genital Tract Infections. Washington, DC: American Society for Microbiology, 1993

14. Summanen P, Baron EJ, Citron DM, et al. Wadsworth Anaerobic Bacteriology Manual, 5th edn. Belmont, CA: Star Publishing Company, 1993

15. Shepard MC. Culture media for ureaplasmas. In Razin S, Tully JG, eds. Methods in Mycoplasmology, Vol I. New York: Academic Press, 1983:397-401

16. Funke G, Bernard K. Corynebacterium Grampositive rods. In Murray P, ed. Manual of Clinical Microbiology. Washington, DC: American Society for Microbiology, 1999:319-45

17. Moncla BJ, Braham P, Rabe L, Hillier SL. Rapid presumptive identification of black-pigmented gram negative anaerobic bacteria by using 
4-methylumbelliferone derivates. J Clin Microbiol 1991;29:1955-8

18. Moncla BJ, Braham P, Hillier SL. Sialidase (neuraminidase) activity among gram-negative anaerobic and capnophilic bacteria. J Clin Microbiol 1990;28:422-5

19. Wallace C, Kenny G, Schachter J. Cumitech 19: Laboratory Diagnosis of Chlamydial and Mycoplasmal Infections. Washington, DC: American Society for Microbiology, 1984

20. Thomason JL, Gelbart S, Anderson RJ, et al. Statistical evaluation of diagonostic criteria for bacterial vaginosis. Am J Obstet Gynecol 1990;162: $155-60$

21. Hillier SL, Krohn MA, Rabe LK, et al. The normal vaginal flora, $\mathrm{H}_{2} \mathrm{O}_{2}$ producing lactobacilli and bacterial vaginosis in pregnant women. Clin Infect Dis 1993;16(Suppl):S273-S281

22. Puapermpoonsiri S, Kato N, Watanabe K, et al. Vaginal microflora associated with bacterial vaginosis in Japanese and Thai pregnant women. Clin Infect Dis 1996;23:748-52

ReCeIVED 7/12/00; ACCEPTED 11/10/00
23. SmayevskyJ, Roldan L, Fernandez Canigia L, et al. Utility of the Gram stain and the sialidase detection for diagnosis of bacterial vaginosis in non-pregnant women. Int J Gynecol Obstet 1999;67(Suppl):S51

24. Odin L. Sialic acid in human cervical mucus, in hog seminal gel and in ovomucin. Acta Chem Scand 1955;9:1235-6

25. Catlin BW. Gardnerella vaginalis: characteristics, clinical considerations and controversies. Clin Microbiol Rev 1992;5:213-37

26. Spiegel C, Eschenbach D, Amsel R, Holmes KK. Curved anaerobic bacteria in bacterial non specified vaginosis and their response to antimicrobial therapy. J Infect Dis 1983;148:817-23

27. Taylor-Robinson D. Infections due to species of mycoplasmas and ureaplasma: un update. Clin Infect Dis 1996;23:671-82

28. Smayevsky J, Bianchini H, Bagnati E, et al. Aislamiento de Gardnerella vaginalis y Mycoplasma hominis en vaginosis bacteriana. Infect Microbiol Clin 1989;1:59-61 


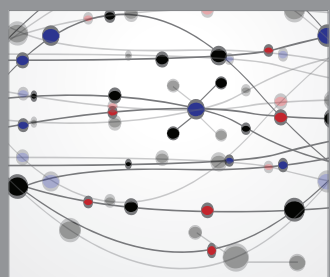

The Scientific World Journal
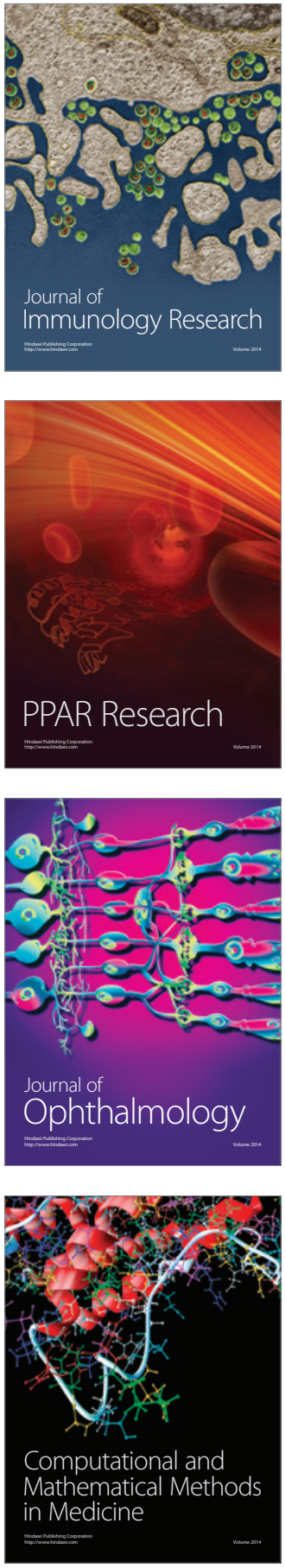

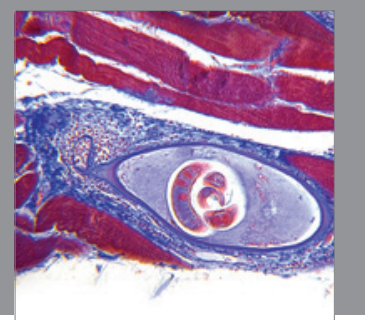

Gastroenterology

Research and Practice
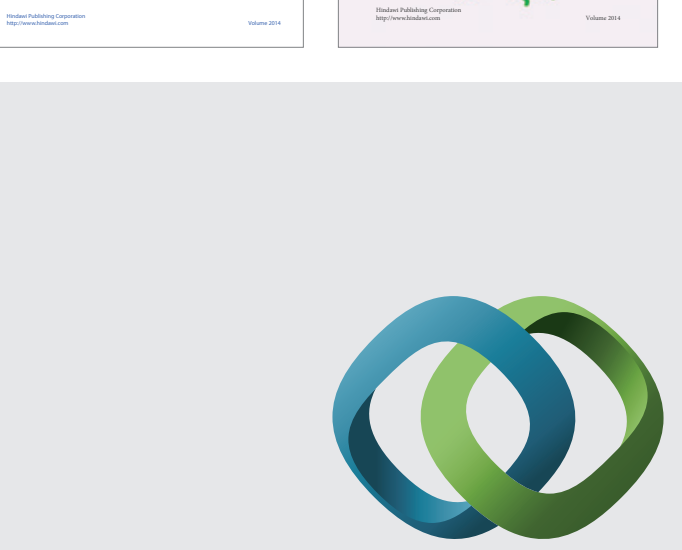

\section{Hindawi}

Submit your manuscripts at

http://www.hindawi.com
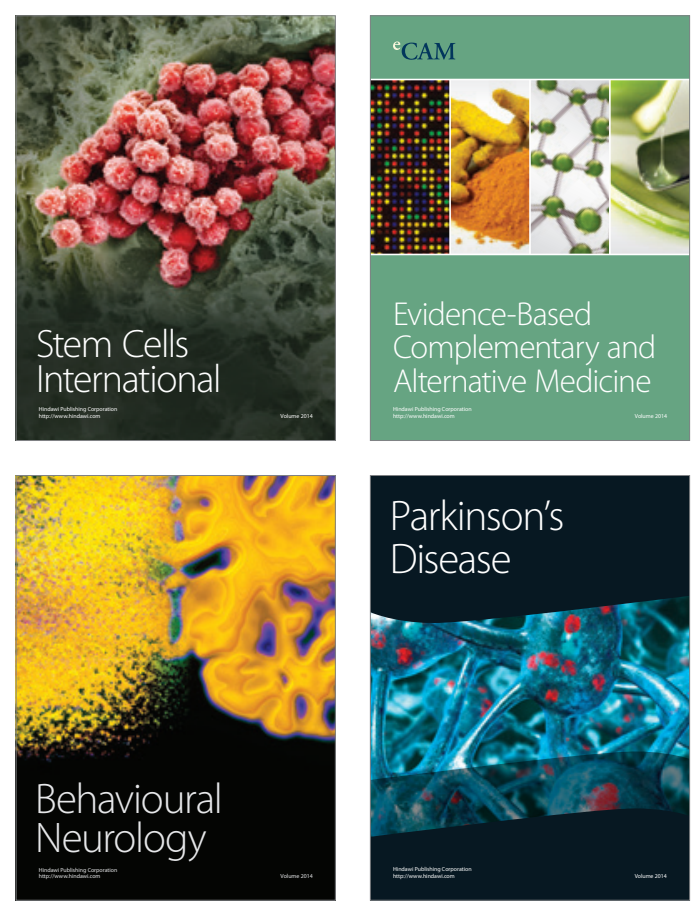

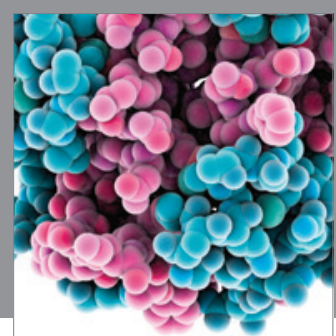

Journal of
Diabetes Research

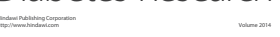

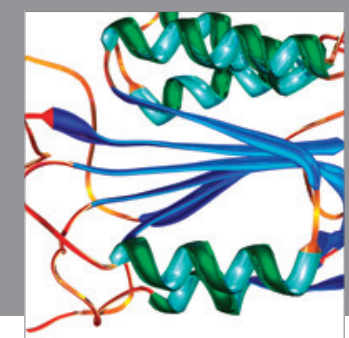

Disease Markers
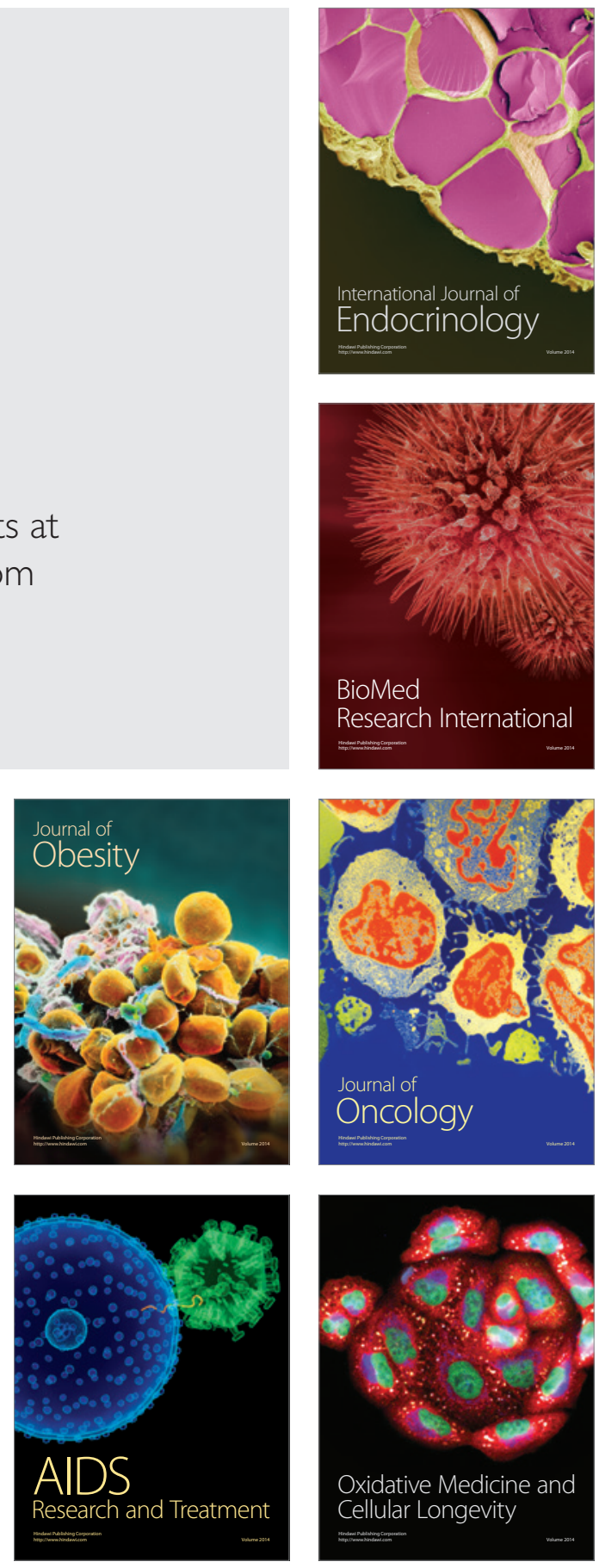